\title{
Effect of Acute Polycythemia on Newborn Renal Hemodynamics and Function
}

\author{
UMA R. KOTAGAL ${ }^{(18)}$ AND LEONARD I. KLEINMAN \\ Department of Pediatrics and Physiology, University of Cincinnati College of Medicine, 231 Bethesda Avenue, \\ Cincinnati, Ohio USA and the Cincinnati Children's Hospital Research Foundation
}

\begin{abstract}
Summary
The present study investigates the effects of polycythemia on renal hemodynamics and function in 15 anesthetized newborn dogs, 2-10 days of age. Microspheres were used to study renal blood flow. Experimental animals received an exchange transfusion with adult dog packed red blood cells resulting in an increase in hematocrit from $38 \% \pm 2.1 \%$ to $69 \% \pm 2.1 \%$. Control animals received an exchange transfusion with adult dog whole blood so that there was no change in hematocrit.

Polycythemia resulted in a marked increase in blood viscosity, a $40 \%$ fall in cardiac output from $251.8 \pm 14 \mathrm{ml} / \mathrm{kg} / \mathrm{min}$ to 150.7 $\pm 9 \mathrm{ml} / \mathrm{kg} / \mathrm{min}$ and a $98 \%$ increase in total vascular resistance from $0.32 \pm 0.02 \mathrm{mmHg} / \mathrm{ml} / \mathrm{kg} / \mathrm{min}$ to $0.63 \pm 0.07 \mathrm{mmHg} / \mathrm{ml} /$ $\mathrm{kg} / \mathrm{min}$. Nevertheless, renal blood flow was not significantly altered indicating renal vasodilation $(1.4 \pm 0.06 \mathrm{ml} / \mathrm{g} / \mathrm{min}$ initial versus $1.2 \pm 0.09 \mathrm{ml} / \mathrm{g} / \mathrm{min}$ final). Although renal blood flow was well preserved, renal plasma flow decreased by $63 \%$ as the hematocrit increased from $0.86 \pm 0.03 \mathrm{ml} / \mathrm{g} / \mathrm{min}$ to $0.38 \pm 0.04 \mathrm{ml} / \mathrm{g} /$ min, resulting in a 53\% fall in glomerular filtration rate from 0.21 $\pm 0.02 \mathrm{ml} / \mathrm{min} / \mathrm{g}$ kidney weight to $0.09 \pm 0.02 \mathrm{ml} / \mathrm{min} / \mathrm{g}$ kidney weight. There was also a large drop in urine output and $\mathrm{Na}$ and $\mathrm{K}$ excretion following jolycythemia. This was due primarily to the decreased filtered load, because fractional $\mathrm{Na}$ reabsorption remained constant.
\end{abstract}

Thus, in spite of well-preserved renal blood flow, polycythemia markedly affected renal function, resulting in water and salt retention.

\section{Speculation}

These effects of polycythemia on renal hemodynamics and function in newborn animals could account for the oliguria seen in newborn polycythemic infants. Newborn infants with polycythemia should be watched closely for problems of salt and water retention.

The regulation of renal hemodynamics is a complex process and has been extensively investigated. Renal vascular resistance is obviously an important part of this complex mechanism and factors affecting resistance, therefore, play a major role in altering renal blood flow and intrarenal hemodynamics. Changes in the circulating mass of red blood cells or more importantly, their concentration, affect vascular resistance by altering blood viscosity and these changes could thus profoundly affect the kidney.

Earlier studies have evaluated the role of altered blood viscosity on the kidney (10-15). In most of these studies, however, blood volume and/or plasma colloids were also altered as hematocrit was changed $(10-13,15)$, thus modifying the effects of changing hematocrit. Schrier, et al. (14) studied the effect of increasing and decreasing hematocrit on renal hemodynamics while maintaining a constant blood volume and plasma protein. The range of hematocrits studied was usually from normal to relatively low values. In addition, all the above studies were on adult animals.
Newborn infants have hematocrits that are greater than adults, the average hematocrit being 55\% (17). High hematocrits have also been found in newborn nonhuman animals (5). Furthermore, $8 \%$ of newborn infants have hematocrits greater than $65 \%$ and may have problems related to the effects of polycythemia and altered viscosity $(6,17)$. There are also differences in renal function and renal hemodynamics between the newborn and adult animal (8), so that results of experiments dealing with effects of changing hematocrit on renal hemodynamics and function in adult animals may not necessarily apply to the newborn animal. For these reasons, the effects of increasing hematocrit on renal hemodynamics in a newborn animal model were studied.

\section{MATERIALS AND METHODS}

Studies were performed on 15 newborn dogs 2-10 days of age. The puppies were taken from their mothers at the time of the experiment and were anesthetized with intravenous pentobarbital, $25 \mathrm{mg} / \mathrm{kg}$ body weight. They were then placed on a temperature controlled operating board regulated to maintain rectal temperature at $37^{\circ} \mathrm{C}$. The trachea was exposed and cannulated for suction and ventilatory support when needed.

Polyethylene catheters of appropriate size (either PE-50, 60 or 90) were placed in the right jugular vein for infusion of maintenance fluids, sampling of blood and infusion of blood during the exchange transfusion; and in the left jugular vein for infusion of inulin. A catheter was placed in the abdominal aorta through the femoral artery for monitoring blood pressure, arterial blood sampling, withdrawal of blood during the exchange transfusion and for obtaining the reference blood sample during microsphere injection. Both ureters were catheterized for urine collection. A catheter was placed into the left ventricular cavity (via the left carotid artery) for the injection of microspheres. The position of the left ventricular catheter was confirmed by pressure tracings and reconfirmed at autopsy. All animals (controls and experimental) received a constant intravenous infusion of a solution containing glucose (50 g/liter), $\mathrm{Na}$ ( $25 \mathrm{mEq} /$ liter $), \mathrm{K}$ (20 mEq/liter), chloride $(22 \mathrm{mEq} /$ liter $)$, magnesium $(3 \mathrm{mEq} /$ liter $)$, lactate $(25$ $\mathrm{mEq} /$ liter $)$ and phosphate $(3 \mathrm{mEq} /$ liter $)$ during the experiment at a rate of $0.11 \mathrm{ml} / \mathrm{kg} / \mathrm{min}$ to ensure hydration and adequate urine output.

Immediately after surgery, a priming dose of $4 \mu \mathrm{Ci} / \mathrm{kg}$ of $\left[{ }^{3} \mathrm{H}\right]$ methoxy-labeled inulin, diluted in maintenance solution, was given. This was followed by inulin, infused at $4 \mu \mathrm{Ci} / \mathrm{kg} / \mathrm{h}$, in order to reach steady state levels for subsequent inulin clearances. Timed urine collections were obtained to determine urine inulin, $\mathrm{Na}$ and $\mathrm{K}$ excretion rates. At the midpoint of urine collection, blood samples were obtained to determine serum inulin, $\mathrm{Na}$ and $\mathrm{K}$ concentrations. Glomerular filtration rate was equated with inulin clearance. From the simultaneous serum and urinary inulin, $\mathrm{Na}$ and $\mathrm{K}$ concentrations, filtration, reabsorption and excretion of $\mathrm{Na}$ and $\mathrm{K}$ were calculated. Clearance studies were obtained twice in each animal just prior to each microsphere study. 
The microsphere reference organ technique was used to determine cardiac output and renal blood flow. $(2-4,7)$. Approximately $150-200,000$ carbonized microspheres $15 \mu \mathrm{m}$ in diameter and labeled with different isotopes were injected into the left ventricle over a $10 \mathrm{sec}$ period. Simultaneously, a reference blood sample was withdrawn from the descending aorta (via the femoral artery) at a constant rate using a withdrawal pump starting just prior to the injection and ending $1.5 \mathrm{~min}$ after injection of the microspheres to determine the concentration of spheres in the blood. Criteria described for validity of use of radioactive microspheres (7) were satisfied in these experiments.

Cardiac output and renal blood flows were studied twice in each animal. The first measurement, a baseline determination, was made $1 \mathrm{~h}$ after recovery from anesthesia. The second determination was made $1-1 / 2 \mathrm{~h}$ after the end of the experimental procedure. At the conclusion of the experiments, the animals were killed by an overdose of pentobarbital. The kidneys were removed from the animal, weighed, allowed to dry overnight and then weighed and placed in a Packard auto gamma spectrometer and the radioactivity counted. These methods have been described in detail in an earlier paper (8). Although a relatively narrow range of spectral activity for each isotope was chosen, complete separation of the isotopes was not achieved and crossover between the different isotopes was resolved by simultaneous equations.

Cardiac output and renal blood flow were calculated using the following formulas:

Cardiac output $=\frac{\text { Total counts injected }}{\text { Total femoral blood counts }}$

$\times$ Blood removal rate $(\mathrm{ml} / \mathrm{min})$

Renal blood flow $=\frac{\text { Total kidney counts }}{\text { Total femoral blood counts }}$

$\times$ Blood removal rate $(\mathrm{ml} / \mathrm{min})$

Renal blood flow is expressed in terms of wet kidney weight. Renal plasma flow was calculated from renal blood flow and hematocrit. Arterial hematocrit was determined in heparinized capillary tubes centrifuged at $12,600 \times \mathrm{g}$ for $5 \mathrm{~min}$. Plasma protein was determined using a calibrated refractometer (American Optical Co.). Whole blood viscosity was measured in vitro in a Brookfield Microviscometer LVT at various shear rates (16). Heart rate, respiratory rate, electrocardiogram, blood pressure and rectal temperatures were continuously monitored during the experiment using a Hewlett-Packard recorder and oscilloscope. Arterial blood gases were measured periodically using a Radiometer microelectrode unit. Tritiated inulin activity was determined in duplicate on blood and urine samples using a Packard Tricarb scintillation spectrometer. $\mathrm{Na}$ and $\mathrm{K}$ were measured in duplicate on blood and urine samples by atomic absorption.

The animals were divided into two groups. Group I consisted of five animals (3-10 days of age) that served as controls and received an exchange transfusion of $60-70 \mathrm{ml} / \mathrm{kg}$ of adult dog whole blood by means of a simultaneous infusion-withdrawal syringe pump so that there was no change of hematocrit or blood volume before and after the exchange tranfusion. Group $I I$ consisted of 10 animals (2-8 days of age) that received adult dog packed red blood cells during the exchange transfusion. This resulted in a rise in hematocrit but no apparent change in blood volume because the volume infused was matched by simultaneous withdrawal of an equal volume of blood from the animal. There were no differences between the two groups before the tranfusions.

All results were calculated with standard statistical computer programs available at the University of Cincinnati. The results of the experimental procedure were compared to baseline determinations made on the same animal by paired $t$ test. Statistical results are presented as mean \pm S.E.

Preliminary studies were performed in six newborn puppies, $3-$ 28 days of age, in order to determine the following: (a) if there were complete extraction of microspheres across the renal vascular bed before and after the production of polycythemia and (b) to measure the effect of polycythemia on central venous pressure and renal venous pressure. Polycythemia was produced by an exchange tranfusion with adult dog packed red cells identical to that in the experimental group (Group II). In these animals, in addition to the surgical procedures described above, a narrow bore polyethylene catheter (PE-10) was placed in the renal vein using techniques described in detail in a previous paper (9). Following injection of microspheres into the left ventricle, a sample of blood was collected from the renal vein for $3 \mathrm{~min}$ and the radioactivity counted.

\section{RESULTS}

Validation studies. In the preliminary studies performed on the six dogs outlined above, there was complete extraction of microspheres by the kidney with less than $0.5 \%$ of the microspheres appearing in the renal vein both before and after polycythemia. Polycythemia did not produce any alteration in central venous pressure (mean \pm S.E.) $(5.0 \pm 0.7 \mathrm{mmHg}$ initial versus $4.9 \pm 0.7$ $\mathrm{mmHg}$ final) or renal venous pressure (mean \pm S.E.) $(7.5 \pm 1.2$ $\mathrm{mmHg}$ initial versus $6.6 \pm 0.80 \mathrm{mmHg}$ final). Inasmuch as the addition of the renal venous catheter involved extensive surgery and no effects on renal venous pressure were seen, vascular resistance across the renal bed in subsequent experiments was calculated using mean arterial blood pressure without correction for renal venous pressure. Similarly, since central venous pressure remained unchanged following polycythemia, peripheral vascular resistance was calculated as the ratio of mean arterial blood pressure to cardiac output.

No transfusion reactions occurred in either control or experimental animals. In control animals (Group I), there were no effects of exchange transfusion with adult whole blood on hematocrit or any of the physiologic functions studied (Table 1). The values for arterial blood pressure, renal hemodynamics and renal function in control animals are similar to values reported in newborn puppies in earlier studies $(8,9)$. Results of the experimental group (Group II) are presented with the baseline determination as control values for each animal. There were no significant differences in $\mathrm{pH}, \mathrm{PCO}_{2}$, or total protein before and after the exchange tranfusion.

Hematocrit and viscosity. Puppies receiving an exchange transfusion with packed adult dog red blood cells experienced an increase in hematocrit from $38 \% \pm 2 \%$ initially to $69 \% \pm 2 \%$ after

Table 1. Renal hemodynamics and renal function in controls $(n=5)$

\begin{tabular}{|c|c|c|c|}
\hline & $\begin{array}{c}\text { Before } \\
\text { exchange } \\
\text { transfusion }\end{array}$ & $\begin{array}{c}\text { After } \\
\text { exchange } \\
\text { transfusion }\end{array}$ & \\
\hline Hematocrit & $35 \pm 3.5^{1}$ & $35 \pm 3.0^{1}$ & $\mathrm{~ns}^{2}$ \\
\hline $\begin{array}{r}\text { Cardiac output } \\
(\mathrm{ml} / \mathrm{kg} / \mathrm{min})\end{array}$ & $213 \pm 9$ & $212 \pm 11$ & ns \\
\hline $\begin{array}{l}\text { Mean blood pressure } \\
(\mathrm{mmHg})\end{array}$ & $65 \pm 4$ & $67 \pm 5$ & ns \\
\hline $\begin{array}{l}\text { Renal blood flow } \\
(\mathrm{ml} / \mathrm{g} / \mathrm{min})\end{array}$ & $1.8 \pm 0.13$ & $1.9 \pm 0.15$ & ns \\
\hline $\begin{array}{l}\text { Renal plasma flow } \\
(\mathrm{ml} / \mathrm{g} / \mathrm{min})\end{array}$ & $1.22 \pm 0.08$ & $1.25 \pm 0.09$ & ns \\
\hline Filtration fraction & $0.25 \pm 0.03$ & $0.23 \pm 0.03$ & ns \\
\hline $\begin{array}{l}\text { Urine output } \\
\text { (ml/min) }\end{array}$ & $0.049 \pm 0.009$ & $0.050 \pm 0.01$ & ns \\
\hline $\mathrm{U}_{\mathrm{NA}} \mathrm{V}^{3}(\mu \mathrm{eq} / \mathrm{min})$ & $2.9 \pm 1.0$ & $3.1 \pm 1.1$ & ns \\
\hline $\mathrm{U}_{\mathrm{K}} \mathrm{V}^{3}(\mu \mathrm{eq} / \mathrm{min})$ & $2.6 \pm 1.4$ & $2.8 \pm 1.5$ & ns \\
\hline
\end{tabular}

\footnotetext{
${ }^{1}$ Values are mean \pm S.E.

${ }^{2}$ Not significant.

${ }^{3} U_{\mathrm{NA}} \mathrm{V}$, excreted $\mathrm{Na} ; \mathrm{U}_{\mathrm{K}} \mathrm{V}$, excreted $\mathrm{K}$.
} 
the transfusion $(P<0.01)$. As shear rates decrease (lower flow rates), viscosity increases and this increase in viscosity is potentiated in higher hematocrits. As hematocrit increased from 38 to 69 , blood viscosity at a shear rate of $230 \mathrm{sec}^{-1}$ increased in a nonlinear fashion from 3.2 to 9.4 centipoises, an increase of $185 \%$ $(P<0.01)$, and at a shear rate of $23 \mathrm{sec}^{-1}$, blood viscosity increased from 5.0 to 15.8 , an increase of $200 \%(P<0.01)$.

Cardiac output. The effect of the experimental procedure on cardiac output and vascular resistance is shown in Figure 1. After polycythemia, cardiac output decreased significantly from 251.8 $\pm 14 \mathrm{ml} / \mathrm{kg} / \mathrm{min}$ before the transfusion to $150.7 \pm 9 \mathrm{ml} / \mathrm{kg} / \mathrm{min}$ following the transfusion $(P<0.01)$, a fall of $40 \%$. Mean blood pressure increased significantly following polycythemia $(77 \pm 2.5$ $\mathrm{mmHg}$ initially versus $90 \pm 3.7$ final, $P<0.01$ ). Heart rate increased in all animals following polycythemia (170 \pm 5 initially versus $183 \pm 7$ final, $P<0.01$ ). Concomitantly, in the polycythemic animals, peripheral vascular resistance increased markedly with the increase in hematocrit $(0.32 \pm 0.02 \mathrm{mmHg} / \mathrm{ml} / \mathrm{kg} / \mathrm{min}$ initially versus $0.63 \pm 0.07 \mathrm{mmHg} / \mathrm{ml} / \mathrm{kg} / \mathrm{min}$ final, $P<0.01$ ).

Renal blood flow, Renal plasma flow and Renal vascular resistance. The effects of polycythemia on renal hemodynamics are shown in Figure 2. Renal blood flow was not altered significantly following polycythemia $(1.4 \pm 0.06 \mathrm{ml} / \mathrm{gm} / \mathrm{min}$ initially versus 1.2 $\pm 0.09 \mathrm{ml} / \mathrm{gm} / \mathrm{min}$ final, $P>0.2$ ). On the other hand, renal plasma flow decreased markedly from $0.86 \pm 0.03 \mathrm{ml} / \mathrm{gm} / \mathrm{min}$ initially to $0.38 \pm 0.04 \mathrm{ml} / \mathrm{gm} / \mathrm{min}$ after the transfusion, a fall of about 55\% $(P<0.05)$. The fraction of cardiac output going to the kidney increased by $61 \%$ from $5.7 \pm 0.5$ to $8.8 \pm 1.4(P<0.05)$. Increasing the hematocrit increased renal vascular resistance from $57.9 \pm 4.1 \mathrm{mmHg} / \mathrm{ml} / \mathrm{gm} / \mathrm{min}$ to $85 \pm 9.0 \mathrm{mmHg} / \mathrm{ml} / \mathrm{gm} / \mathrm{min}$, a rise of about $40 \%(P<0.05)$.

Renal function. Polycythemia caused a significant decrease in glomerular filtration rate (Figure 3), from $0.21 \pm 0.02 \mathrm{ml} / \mathrm{min} / \mathrm{g}$
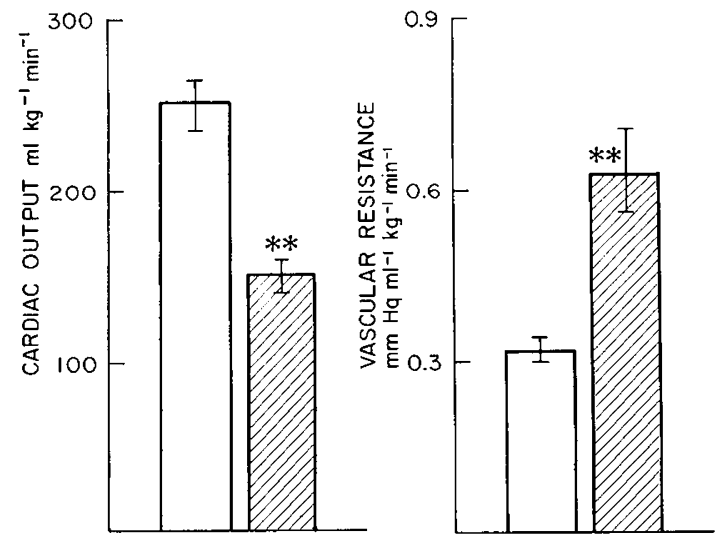

Fig. 1. Cardiac output and peripheral vascular resistance before (not shaded) and after (shaded) polycythemia. (Mean \pm S.E.) ${ }^{* *} P<0.01$

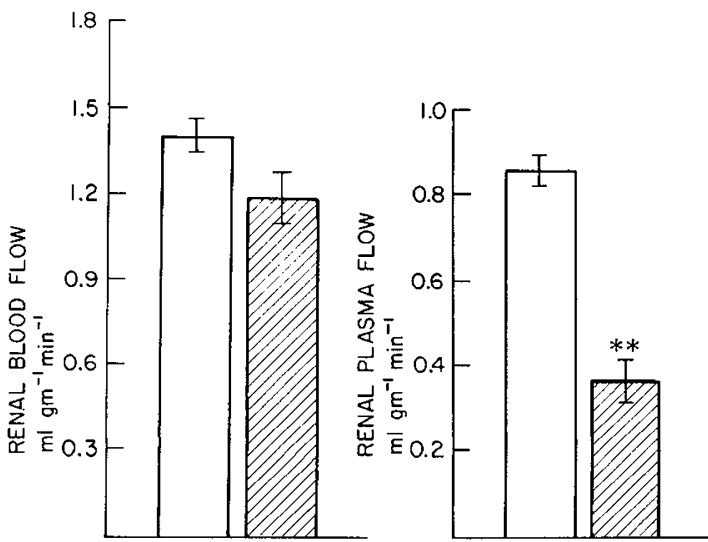

Fig. 2. Renal blood flow and renal plasma flow before (not shaded) and after (shaded) polycythemia. (Mean \pm S.E.) ${ }^{* *} P<0.01$

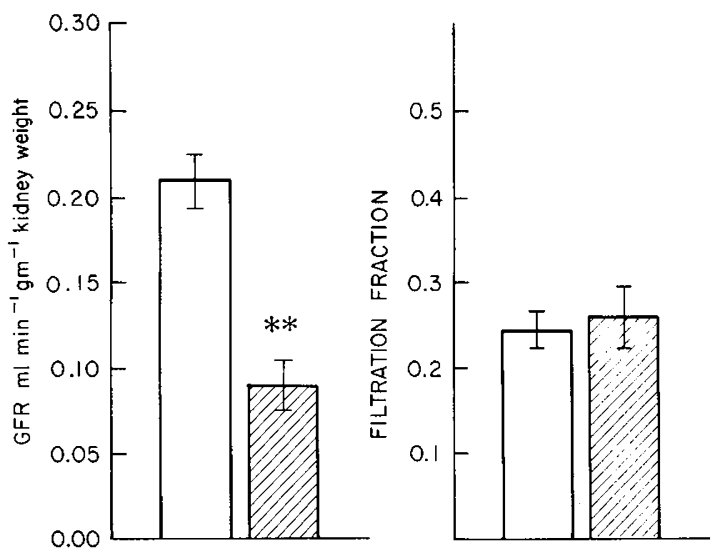

Fig. 3. Glomerular filtration rate per g kidney weight and filtration fraction before (not shaded) and after (shaded) polycythemia. (Mean \pm S.E.) ${ }^{* *} P<0.01$

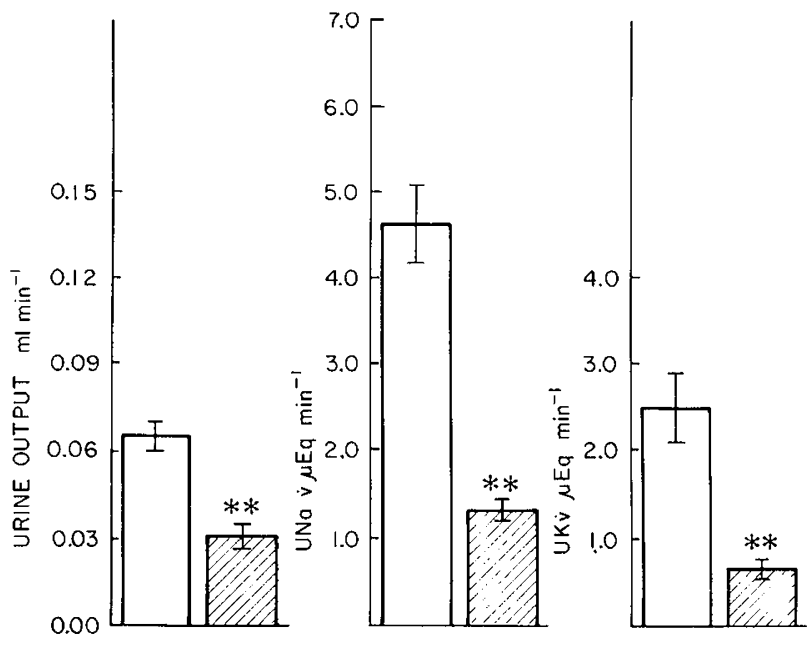

Fig. 4. Urine output, urine $\mathrm{Na}$ and urine $\mathrm{K}$ excretion before (not shaded) and after (shaded) polycythemia. (Mean \pm S.E.) ${ }^{* *} P<0.01$

kidney weight to $0.09 \pm 0.02 \mathrm{ml} / \mathrm{min} / \mathrm{g}$ kidney weight $(P<0.01)$. The ratio of glomerular filtration rate to renal plasma flow (filtration fraction) increased slightly after polycythemia ( 0.24 initially versus 0.26 final), but this failed to reach statistical significance $(P$ $=0.2$ ).

The effect of polycythemia on renal function is shown in Figure 4. Following polycythemia, urine output decreased to $45 \%$ of the control value, from $0.067 \pm 0.006 \mathrm{ml} / \mathrm{min}$ to $0.030 \pm 0.004 \mathrm{ml} /$ $\min (P<0.01)$. Even though tubular reabsorption of $\mathrm{Na}$ and $\mathrm{K}$ per $\mathrm{ml}$ glomerular filtration rate was not significantly altered, $\mathrm{Na}$ excretion fell by $76 \%$ from $4.65 \pm 0.47 \mu \mathrm{eq} / \mathrm{min}$ before the transfusion to $1.32 \pm 0.13 \mu \mathrm{eq} / \mathrm{min}$ after the increase in hematocrit $(P<0.01)$. Polycythemia also resulted in a significant fall in renal potassium excretion $(2.52 \pm 0.40 \mu \mathrm{eq} / \mathrm{min}$ initially versus $0.68 \pm$ $0.09 \mu \mathrm{eq} / \mathrm{min}$ final, $P<0.01$ ).

There was no effect of age on the renal response to polycythemia $(r=0.4)$ over the developmental period studied.

\section{DISCUSSION}

After polycythemia there was a 2 to 3 -fold increase in whole blood viscosity with a corresponding increase in peripheral vascular resistance. Associated with the rise in vascular resistance was a significant fall in cardiac output. In spite of the marked fall in cardiac output and increase in overall peripheral vascular resistance, renal blood flow was relatively well preserved. Renal vascular resistance increased only slightly $(40 \%)$ compared with what might be predicted from the increase in blood viscosity (185\%) and overall peripheral vascular resistance $(100 \%)$. There was, therefore, some factor in the renal circuit that resulted in renal 
vasodilatation. Although the renal vasodilatation may theoretically have been passive, due to a rise in transmural vascular pressure, the increase in arterial blood pressure was comparatively small. This suggests that the renal vasodilatation probably represented an active process. McDonald (11) studied the effect of altered blood viscosity on renal blood flow in adult dogs by altering hematocrit and found similar results. The renal vasodilatation in the puppies, however, is surprising in view of previous studies from our laboratory demonstrating that newborn dogs, in contrast to adult dogs, were unable to decrease renal vascular resistance and thus maintain renal blood flow when renal perfusion pressure was lowered (9). Thus mechanisms involved in maintaining blood flow in polycythemia appear to be different from those involved in hypotension.

In spite of the absence of fall in renal blood flow, renal plasma flow decreased significantly as the hematocrit increased. With the fall in the renal plasma flow, glomerular filtration rate was also decreased. Filtration fraction was not changed significantly following polycythemia, since the fractional fall in glomerular filtration rate was similar to that for renal plasma flow. This finding of negligible change in filtration fraction contrasts to earlier studies by Spencer (15), Schrier and Earley (14) and Marshall, et al. (10) in which it is reported that the filtration fraction in adult dogs increased significantly with increasing hematocrit. The differences in results between these studies and ours may be explained either by differences between adult and newborn animals or by differences in experimental procedure. In the present study, polycythemia was produced without accompanying hypervolemia; however, polycythemia was associated with an increase in blood volume in the study by Spencer (15). On the other hand, Marshall, et al. (10) produced polycythemia by intermittent exposure to gradually lowered barometric pressure, presumably without resultant hypervolemia. However, in all of these studies, measurements of renal plasma flow were made using PAH clearance with no correction for renal extraction of PAH. It is possible that PAH clearance in their studies may not have accurately represented renal plasma flow since polycythemia may have altered renal extraction of PAH.

Aperia, et al. (1) studied renal function in polycythemic newborn infants before and after isovolemic hemodilution. They demonstrated that polycythemic newborn infants had lower glomerular filtration rate, urine output and urinary $\mathrm{Na}$ excretion. After hemodilution in the infants, Aperia, et al. found a decrease in hematocrit and viscosity associated with a marked increase in the glomerular filtration rate, urine output, and urinary sodium excretion. The increase in water and $\mathrm{Na}$ excretion was out of proportion to the increase in glomerular filtration rate suggesting that tubular reabsorption of water and $\mathrm{Na}$ was altered during hemodilution. Our results agree with Aperia's study in that glomerular filtration rate, urine output and urinary $\mathrm{Na}$ excretion were lower during polycythemia; however, in the present study the fall in urinary $\mathrm{Na}$ excretion was due primarily to a decrease in the filtered $\mathrm{Na}$ load since reabsorption of $\mathrm{Na}$ per unit glomerular filtration rate was not significantly altered. The differences between Aperia's study and this study may be related to differences in mechanisms of production of polycythemia. The newborn infants in their study were polycythemic due to delayed clamping of the umbilical cord (1) and were probably hypervolemic with expanded red cell volume and plasma volume which would result in altered oncotic pressures. In the present study, polycythemia was produced by an exchange transfusion with packed red blood cells with no change in blood volume. Second, our studies on newborn puppies were performed 1 to $1-1 / 2 \mathrm{~h}$ after the production of polycythemia whereas the initial renal function studies in the newborn infants were done several $h$ following the placental transfusion and the final renal function studies done as long as 14 $h$ after hemodilution. Finally, of course, there may be a difference in response between the newborn human and the dog. In summary, the results of the present investigation demonstrate that in polycythemic newborn dogs, in spite of the increased blood viscosity and decreased cardiac output, renal blood flow is well preserved. Even though renal blood flow was well maintained following polycythemia, renal plasma flow was almost halved and this resulted in a fall in glomerular filtration rate which in turn resulted in decreased water, $\mathrm{Na}$ and $\mathrm{K}$ excretion.

\section{REFERENCES AND NOTES}

1. Aperia, A., Bergqvist, G., Broberger, O., Thodenius, K., and Zetterstrom, R.: Renal function in newborn infants with high hematocrit values before and after isovolemic haemodilution. Acta Paediatr. Scand., 63: 878 (1974).

2. Archie, J. P., Jr., Fixler, D. E., Ullyot, D. J., Hoffman, J. I., Utley, J. R., and Carlson, E. L.: Measurement of cardiac output with an organ trapping of radioactive microspheres. J. Appl. Physiol., 35: 148, (1973).

3. Archie, J. P., Jr.: Equations for the determination of major regional blood flow in the mammalian fetus with radioactive microspheres. Cardiovasc. Res., 8: 81 (1974).

4. Bartrum, R. J., Jr., Berkowitz, D.M., Hollenberg, N. K.: A simple radioactive microsphere method for measuring regional flow and cardiac output. Invest. Radiol. 9: 126 (1974)

5. Deavers, S. I., Huggins, R. A., and Sheng, H. P.: Blood volume changes during the first week after birth in the beagle and pig. Proc. Soc. Exp. Biol. Med., 159(1): 152, (1978).

6. Gross, G. P., Hathaway, W. E., and McGaughey, H. R.: Hyperviscosity in the neonate. J. Pediatr., 82: 1004 (1973).

7. Heymann, M. A., Payne, B. D., Hoffman, J. I., and Rudolph, A. M.: Blood flow measurements with radionuclide-labeled particles. Prog. Cardiovasc. Dis., 20(1): 55 (1977).

8. Kleinman, L. I., and Reuter, J. H.: Maturation of glomerular blood flow distribution in the new-born dog. J. Physiol., (Lond) 228: 91 (1973).

9. Kleinman, L. I., and Lubbe, R. J.: Factors affecting the maturation of glomerular filtration rate and renal plasma flow in the new-born dog. J. Physiol. (Lond), 223: 395 (1972).

10. Marshall, L. H., Hanna, C. H., and Specht, H.: Renal function in dog during increased blood viscosity produced by simulated altitude exposure. Am. J. Physiol. 171: 499 (1952).

11. McDonald, K. M.: Effect of hematocrit and colloid-induced changes in blood viscosity on renal hemodynamics and renin release in the dog. Circ. Res., 40: 112 (1974).

12. Migdal, S., Alexander, E. A. Bruns, F. J. Riley, A. L., Levinsky, N. G.: Effect of hemodilution on the distribution of renal blood flow. Circ. Res., 36(1): 71 (1975).

13. Nashat, F. S., Portal, R. W.: The effects of changes in haematocrit on renal function. J. Physiol. (Lond), 193: 513 (1967).

14. Schrier, R. W., Earley, L. E.: Effects of hematocrit on renal hemodynamics and sodium excretion in hydropenic and volume-expanded dogs. J. Clin. Invest., 49: 1656 (1970).

15. Spencer, M. P.: Renal hemodynamics in experimental polycythemia. Am. J. Physiol., 165: 399 (1951).

16. Wells, R. E. Jr., Denton, R., Merrill, E. W.: Measurement of vicosity of biologic fluids by coneplate viscometer. J. Lab. Clin. Med., 57: 646 (1961).

17. Wesenberg, R. L.: Neonatal 'thick blood' syndrome. Hospital Practice, 13: 137 (1978).

18. Requests for reprints should be addressed to: Dr. Uma R. Kotagal, Department of Pediatrics, Newborn Division, University of Cincinnati College of Medicine, 231, Bethesda Ave., Cincinnati, OH 45267.

19. This research was supported by the Department of Health, Education and Welfare Public Health Service, Project No. 174 "Training in Perinatal Care Research" and the Cincinnati Children's Hospital Research Foundation.

20. Received for publication September 16, 1980.

21. Accepted for publication June 15, 1981. 